\title{
Carbon dioxide flux in the ablation area of Koxkar glacier, western Tien Shan, China
}

\author{
WANG Jian, ${ }^{1}$ HAN Haidong, ${ }^{1}$ ZHANG Shiqiang ${ }^{2}$ \\ ${ }^{1}$ State Key Laboratory of Cryosphere Science, Cold and Arid Regions Environmental and Engineering Research Institute, \\ Chinese Academy of Sciences, Lanzhou, China \\ E-mail: wjshuigong@Izb.ac.cn \\ ${ }^{2}$ Northwest University, Xi'an, China
}

\begin{abstract}
Accelerating loss of glacial mass caused by rising global temperatures has significant implications. The global cycle of the greenhouse gas $\mathrm{CO}_{2}$ is also associated with mineral weathering and glaciation. In glaciated areas, most estimates of atmospheric $\mathrm{CO}_{2}$ consumption are confined to chemical ionic mass balance or analog modeling methods. We applied the gradient method to the surface of Koxkar glacier, western Tien Shan, China, for a 5 month period during 2012. The overall net glaciersystem $\mathrm{CO}_{2}$ exchange (NGE) rate was measured as -0.05 and $-0.07 \mu \mathrm{mol} \mathrm{m}^{-2} \mathrm{~s}^{-1}$ for regions of exposed ice and supraglacial moraine, respectively. This suggests that atmospheric $\mathrm{CO}_{2}$ drawdown may occur during ice melting because of consumption of $\mathrm{H}^{+}$by $\mathrm{CO}_{2}$ hydrolysis that occurs in solutions. Using the degree-day model to calculate glacier ablation in bare-ice regions and considering characteristics of the NGE rate in the supraglacial debris region with the support of GIS, the daily NGE rate was estimated to be $-1.23 \pm 0.17 \mathrm{mmol} \mathrm{m}^{-2} \mathrm{~d}^{-1}$ between Julian days 125 and 268 of 2012 . These findings present a new approach for modeling the dynamics of glacial $\mathrm{CO}_{2}$ sinks undergoing melting, and develop an understanding of the mechanism of atmospheric $\mathrm{CO}_{2}$ exchange.
\end{abstract}

KEYWORDS: atmosphere/ice/ocean interactions, glacier chemistry, ice/atmosphere interactions

\section{INTRODUCTION}

Global mean surface air temperature has increased by $\sim 0.74{ }^{\circ} \mathrm{C}$ over the past 100 years, and is predicted to rise an additional $1.1-6.4^{\circ} \mathrm{C}$ by the end of the present century (Solomon and others, 2007). This warming has influenced alpine glacier fluctuation and runoff, resulting in annual mass losses of up to $3 \mathrm{ma}^{-1}$ (e.g. the European Alps; Zemp and others, 2005). Glacier mass loss is expected to continue, and simulations based on climate warming from greenhouse gases predict a $20 \%$ increase in mean annual discharge of the great Arctic rivers (Macdonald and others, 2005). In China, $82.2 \%$ of all monitored glaciers have retreated, with a total area loss of $4.5 \%$ from the 1950 s to the late 1990 s (Liu and others, 2006).

Because warming-induced alpine glacier melting is likely to intensify, water-rock interactions such as sulfide oxidation and carbonate dissolution are also expected to increase. Glaciation is responsible for a significant drawdown of atmospheric $\mathrm{CO}_{2}$, generating a negative feedback on climate (Sharp and others, 1995; Tranter, 1996; Hodson and others, 2002; Yde and others, 2005; Bartoszewski, 2008). It has long been recognized that rates of terrestrial chemical erosion may influence the atmospheric concentration of $\mathrm{CO}_{2}$, a radiatively important gas contributing to mean global temperature regulation (Raymo and Ruddiman, 1992). Because of its potential impact on climate at glacial-interglacial timescales, $\mathrm{CO}_{2}$ sequestration during episodes of deglaciation has attracted considerable attention (Brown, 2002).

Research on carbon dioxide drawdown in glaciated catchments has been launched in recent years (Hodson and others, 2002; Yde and others, 2005; Krawczyk and others, 2008; Roberts and others, 2008). However, these studies have been almost entirely reliant on the ionic massbalance method of carbon dioxide flux calculations, without direct $\mathrm{CO}_{2}$ concentration and flux monitoring systems. Moreover, eddy covariance data of $\mathrm{CO}_{2}$ flux have been collected over the horizontal surfaces of large ice bodies (Mölg and others, 2003; Cullen and others, 2007; MacDonell and others, 2010; Jarosch and others, 2011) and in complex terrain (Rotach and others, 2003; Hiller and others, 2008; Guo and others, 2011; Jocher and others, 2012). Such an approach may be unsuitable for the study of alpine glaciers, given complex terrain, frequent precipitation and fog, and other factors. The gradient method for collecting and calculating $\mathrm{CO}_{2}$ flux has been used to study net $\mathrm{CO}_{2}$ exchange with the atmosphere in a wide variety of terrains (snow, grassland, forest, bare land, and alpine) (Steffen and others, 2008; Bowling and Massman, 2011; Pumpanen and others, 2011), including complex terrains. Thus, the gradient method may be useful for the study of processes underlying $\mathrm{CO}_{2}$ exchange between the atmosphere and a glacial surface, providing continuous data without interference from precipitation, fog and refrozen condensed water (Bowling and Massman, 2011; Pumpanen and others, 2011).

Using the mass-balance method, total solute fluxes and transient carbon dioxide sinks (which accounted for $14.2 \%$ of total solutes in bulk river water) were estimated at $791.2 \mathrm{~kg}\left(\mathrm{~km}^{2} \mathrm{~d}\right)^{-1}$ and $81.0 \mathrm{~kg}\left(\mathrm{~km}^{2} \mathrm{~d}\right)^{-1}$ in the Koxkar glaciated basin (summer 2004), respectively (Wang and others, 2010). Using the flux gradient method, this paper aims to estimate $\mathrm{CO}_{2}$ fluxes over bare ice and supraglacial moraine at Koxkar glacier during the 2012 melt season. These results, together with other data, may shed light on the influence of atmospheric factors on $\mathrm{CO}_{2}$ fluxes. Specifically, these data provide new insight into $\mathrm{CO}_{2}$ concentrations and fluxes in glaciated basins, which may be used for modeling $\mathrm{CO}_{2}$ change on glacial-interglacial timescales (e.g. Tranter and others, 2002). A further aim is to seek correlations between $\mathrm{CO}_{2}$ flux and other factors across different 


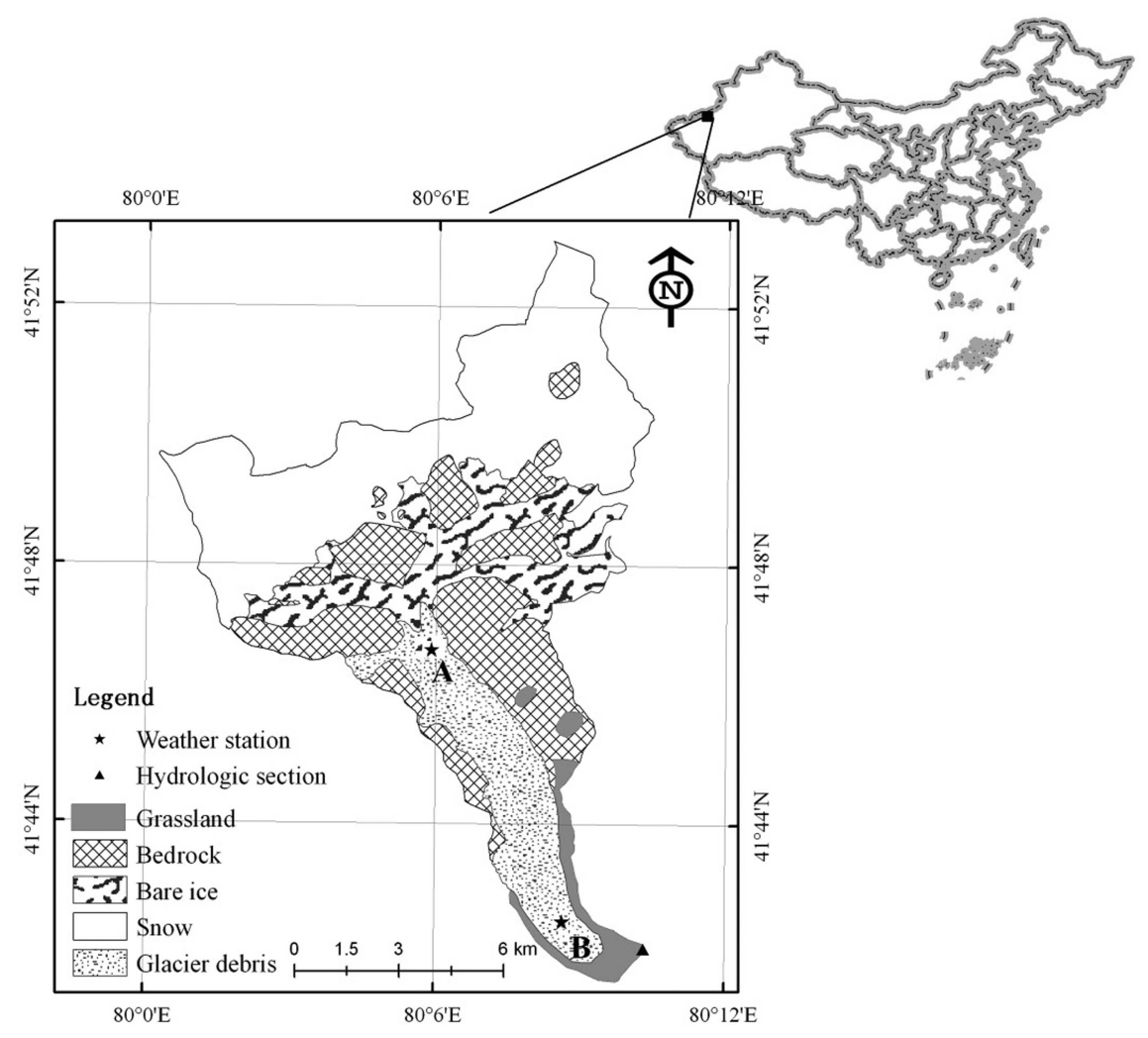

Fig. 1. Map of the Koxkar glacier region (northwest China) sampling sites.

underlying surfaces on Koxkar glacier, which may facilitate conclusions regarding the feedback relationship of glacial change to regional atmospheric $\mathrm{CO}_{2}$ circulation.

\section{SITE DESCRIPTION}

The glaciated Koxkar basin $\left(41^{\circ} 42^{\prime}-41^{\circ} 53^{\prime} \mathrm{N}, 79^{\circ} 59^{\prime}-\right.$ $80^{\circ} 10^{\prime} \mathrm{E}$; Fig. 1) is on the southwest side of Toumuer mountain, northwest China. The glacier is $25.1 \mathrm{~km}$ long and has an area of $83.56 \mathrm{~km}^{2}$. Supraglacial debris covers $\sim 15.6 \mathrm{~km}^{2}$, representing $83 \%$ of the total ablation area (Han and others, 2010). Mean annual air temperature observed near the glacier terminus is $0.77^{\circ} \mathrm{C}$, and mean summer temperature is $7.74^{\circ} \mathrm{C}$ (Han and others, 2008). The main source of precipitation is water vapor from the Atlantic and Arctic Oceans (Kang and others, 1985). Annual precipitation, $81 \%$ of which occurs from May through September, is $\sim 630 \mathrm{~mm}$ at the end of the glacier. Precipitation in the study area is in a solid state (snow and hail). A field investigation from 2003 to 2012 indicated annual discharge at the glacial terminus of $>1.0 \times 10^{8} \mathrm{~m}^{3}$, mainly during the warmer half of the year $(94.5 \%$ of total runoff flux was from May through October).

Two $\mathrm{CO}_{2}$ flux gradient observation stations (Fig. 1) sit atop bare ice (site $\mathrm{A}: 41^{\circ} 47^{\prime} \mathrm{N}, 80^{\circ} 06^{\prime} \mathrm{E} ; 3730 \mathrm{~m}$ a.s.l.) and supraglacial moraine (site $\mathrm{B}$ : $41^{\circ} 43^{\prime} \mathrm{N}, 80^{\circ} 09^{\prime} \mathrm{E}$; $3212 \mathrm{~m}$ a.s.l.). Debris thickness at site $A$ is $<0.01 \mathrm{~m}$ and discontinuous, while the thickness at site $B$ is $\sim 0.70 \mathrm{~m}$. The debris is mainly gray or dark-gray granite stone powder, broken stone particles, and rock mass, which covers $83 \%$ of the total melt area. Therefore, moraine is the principal physical source of crustal dissoluble ions. The nearly horizontal surfaces at sites A and B have an average surface slope less than $2^{\circ}$, and a fetch of several hundred meters in the direction of the prevailing wind, which most often should be a valley-mountain breeze.

\section{METHODS}

During the observation period, we established two synchronous gradient observational systems to measure twotiered $\mathrm{CO}_{2}$ concentrations, wind speed, wind direction, temperature and humidity ( 2.0 and $1.0 \mathrm{~m}$ above the surface), and a series of radiation sensors that included total solar radiation, net radiation and reflection radiation in bare-ice and supraglacial moraine regions. Supraglacial two-tiered $\mathrm{CO}_{2}$ concentrations (2.0 and $1.0 \mathrm{~m}$ above the surface) were determined using infrared $\mathrm{CO}_{2}$ sensors (ES-D type, Sense Air, Sweden), with a variance of $\pm 5.4 \%$ for $\mathrm{CO}_{2}$ (Rinne and others, 2000; Lu and others, 2010; Fang and others, 2011). Data (e.g. $\mathrm{CO}_{2}$ concentration, wind speed, wind direction, temperature, humidity, total solar radiation, net radiation, reflection radiation, and precipitation) were obtained using a PC-3 data acquisition system, and were automatically updated hourly throughout the observation period. Generally, the effective distance was less than ten times the height of the equipment probes. Our gradient observational stations were located in the central part of the glacier, away from nearby grasslands ( $\sim 1.43 \mathrm{~km}$ away), to reduce the possibility of the grassland affecting the $\mathrm{CO}_{2}$ measurement. Unfortunately, we could not obtain synchronous data because of complications with the solar power supply.

The net glacier-system $\mathrm{CO}_{2}$ exchange (NGE) rate between the glacier surface and atmosphere for the temporally and spatially integrated net glacier system is defined as

$$
\mathrm{NGE}=F_{C}+S,
$$

where $F_{C}$ is its vertical flux (upward flux being positive) 
and $S$ is the change of $\mathrm{CO}_{2}$ storage below the $\mathrm{CO}_{2}$ infrared sensors.

We applied the gradient method, in which vertical $\mathrm{CO}_{2}$ fluxes at the glacier surface are estimated by the aerodynamic gradient method (e.g. Sutton and others, 1993). The flux $F_{c}$ of a component with concentration $c$ is calculated from the product of friction velocity $u_{*}$ and a concentration scaling parameter $C_{*}$ as (Rinne and others, 2000; Loubet and others, 2013)

$$
F_{C}=-u_{*} C_{*}
$$

where $u_{*}$ and $c_{*}$ are derived from the stability-corrected gradients of wind speed $(u)$ and $\mathrm{CO}_{2}$ concentration $(c)$ vs height $(z)$ :

$$
u_{*}=k \frac{\mathrm{d} u}{\mathrm{~d}\left[\ln (z-d)-\psi_{\mathrm{m}}\right]},
$$

where $d$ is the zero plane displacement height, which represents the shift in aerodynamic 'ground' because of the presence of the glacier surface, $z$ is the mounting height of the sensors $(2 \mathrm{~m}), k$ is the von Kármán constant with values between 0.35 and 0.43 (usually 0.4), and $\psi_{\mathrm{m}}$ is the integrated stability correction function for momentum.

Harman and others (2008) developed an analytical transfer model for the roughness layer that includes two displacement heights; the model was extended by Siqueira and Katul (2010) to account for stomatal regulation and soil respiration. Harman and others (2008) showed that these additional functions would lead to an additional integral term $\psi_{\mathrm{H}}$ in the concentration profile, which in turn would lead to a new approximation of the concentration scaling parameter $C_{*}$ :

$$
c_{*}=k \frac{\mathrm{d} c}{d\left[\ln (z-d)-\psi_{\mathrm{H}}\left[(z-d) / L-\hat{\psi}_{\mathrm{H}}[(z-d) / L]\right.\right.} .
$$

Siqueira and Katul (2010) give the following expression for $\hat{\psi}_{\mathrm{H}}$ :

$$
\hat{\psi}_{\mathrm{H}}=\left(1-\frac{k S_{n}}{2 \beta} \frac{d_{c}}{d_{m}}\right) \exp \left(-\frac{c_{2 c}}{2} \frac{d_{c}}{d_{m}}\right) E i\left(-\frac{c_{2 c}\left(z-d_{C}\right)}{2 d_{m}}\right),
$$

where $S_{n}$ is the Schmidt number, $\beta=c_{*} / u_{\mathrm{h}}, d_{c}$ and $d_{m}$ are the scalar and momentum displacement heights, and $c_{2 c}$ is a constant that can be taken as 1 in the first approximation. More details of $\psi_{\mathrm{m}}, d_{c}$ and $d_{m}$ are provided by Benjamin and others (2013).

The value for $S$ was calculated from vertical $\mathrm{CO}_{2}$ concentration profiles (Aubinet and others, 2001; Araújo and others, 2010):

$$
S=\frac{P_{\mathrm{a}}}{R T_{\mathrm{a}}} \int_{0}^{h_{\mathrm{m}}} \frac{\partial c}{\partial t} \partial z,
$$

where $P_{\mathrm{a}}$ is atmospheric pressure, $R$ is the molar gas constant, $T_{\mathrm{a}}$ is the air temperature $(\mathrm{K}), h_{\mathrm{m}}$ is the maximum measurement height above ground level (m), $c$ is the $\mathrm{CO}_{2}$ concentration, $t$ is time (s), and $z$ is the height about ground level $(\mathrm{m})$. Details of the $S$ calculation are provided by Valentini and others (2000) and Kowalski (2008).

\section{RESULTS}

\section{$\mathrm{CO}_{2}$ fluctuations}

Typical fluctuations in hourly $\mathrm{CO}_{2}$ concentration, atmospheric temperature and wind speed measured $2 \mathrm{~m}$ above

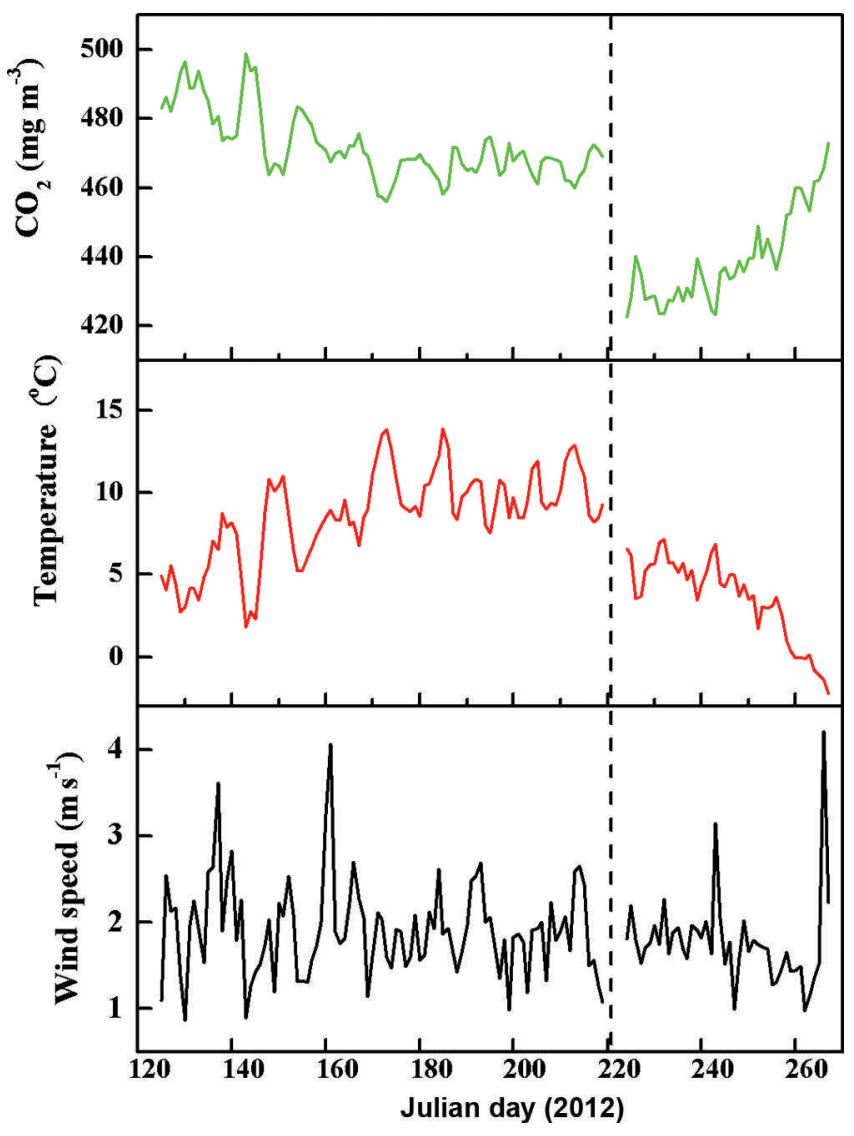

Fig. 2. Fluctuations of hourly $\mathrm{CO}_{2}$ concentration, atmospheric temperature and wind speed above the surface of Koxkar glacier. Data are from bare ice (site A, right of the vertical dotted line) and above supraglacial moraine (site B, left of the vertical dotted line).

bare ice and supraglacial moraine are shown in Figure 2. Mean wind velocity during the observation periods was $2.3 \mathrm{~m} \mathrm{~s}^{-1}$ at both stations. Mean temperatures were $3.4^{\circ} \mathrm{C}$ and $7.6^{\circ} \mathrm{C}$, and the amplitudes of dominant fluctuation in $\mathrm{CO}_{2}$ concentration were $\sim 439.3$ and $472.1 \mathrm{mg} \mathrm{m}^{-3}$ for sites $A$ and $B$, respectively. Variations in $\mathrm{CO}_{2}$ concentration gradually decreased, followed by increasing atmospheric temperature, which otherwise only gradually increased. For example, there is strong negative correlation between $\mathrm{CO}_{2}$ concentration and atmospheric temperature at site $\mathrm{A}$. The associated equation is

$$
C_{\mathrm{CO}_{2}}=-5.333 T_{\mathrm{atm}}+457.4 \quad\left(R^{2}=0.873\right),
$$

where $C_{\mathrm{CO}_{2}}$ is the $\mathrm{CO}_{2}$ concentration $\left(\mathrm{mg} \mathrm{m}^{-3}\right)$, and $T_{\text {atm }}$ is atmospheric temperature $\left({ }^{\circ} \mathrm{C}\right)$ measured $2 \mathrm{~m}$ above the ice surface.

Based on Eqns (7) and (8) for site $\mathrm{B}$, the $\mathrm{CO}_{2}$ concentration was less influenced by atmospheric temperature. Equation (8) shows the relationship between $\mathrm{CO}_{2}$ concentration and atmospheric temperature at site $\mathrm{B}$ :

$$
C_{\mathrm{CO}_{2}}=-3.325 T_{\mathrm{atm}}+497.2 \quad\left(R^{2}=0.910\right) .
$$

Unfortunately, data from sites A and B were not collected simultaneously during the observation period. However, we conclude that the $\mathrm{CO}_{2}$ concentration at site A was dramatically lower than at site B (Fig. 2). This can be explained by the different altitudes and underlying surface conditions at the two sites. 
Table 1. Hourly NGE $\left(\mu \mathrm{mol} \mathrm{m} \mathrm{m}^{-2} \mathrm{~s}^{-1}\right)$ at sites A and B on the surface of Koxkar glacier in 2012

\begin{tabular}{llllll}
\hline Site & Julian days & Max & Min & Mean & Variance \\
\hline A & $220-268$ & 0.48 & -0.74 & -0.05 & 33.07 \\
B & $125-220$ & 0.66 & -1.81 & -0.07 & 60.70 \\
\hline
\end{tabular}

\section{Net glacier-system $\mathrm{CO}_{2}$ exchange (NGE) rate}

During the observation period, hourly NGE ranged from -0.74 to $+0.48 \mu \mathrm{mol} \mathrm{m}^{-2} \mathrm{~s}^{-1}$ at site $\mathrm{A}$ and from -1.81 to $+0.66 \mu \mathrm{mol} \mathrm{m}^{-2} \mathrm{~s}^{-1}$ at site B (Table 1). Amplitudes of dominant hourly NGE fluctuation were approximately -0.05 and $-0.07 \mu \mathrm{mol} \mathrm{m} \mathrm{m}^{-2} \mathrm{~s}^{-1}$ for the bare-ice and supraglacial moraine observation points, respectively. These variance results suggest that the fluctuation range of NGE at the supraglacial moraine (site $A$ variance $=60.70$ ) was greater than at bare ice (site B variance $=33.07$ ). Moreover, the maximum and minimum values of hourly NGE were both recorded at site $\mathrm{B}$. Under normal conditions, upward flux (i.e. $\mathrm{CO}_{2}$ release) occurs with precipitation or at night, when ice melt decreases because of reduced air temperature.

The negative mean values of hourly NGE at the two sites imply that the glacial surface was a sink for atmospheric $\mathrm{CO}_{2}$ during the melt season because of the hydrochemical conditions and mineralogical reactions existing under the ice-melt water (Hodson and others, 2002; Tranter and others, 2002; Yde and others, 2005; Krawczyk and others, 2007, 2008; Lerman and others, 2007). In glaciated regions, these chemical reactions are primarily carbonate and silicate dissolution, for example:

$$
\begin{gathered}
\mathrm{CO}_{2(\text { gas })}+\mathrm{H}_{2} \mathrm{O}_{(\mathrm{aq})} \Leftrightarrow \mathrm{H}_{2} \mathrm{CO}_{3(\mathrm{aq}),} \\
\mathrm{CaCO}_{3(\mathrm{~s})}+\mathrm{H}_{2} \mathrm{CO}_{3(\mathrm{aq})} \Leftrightarrow \mathrm{Ca}_{\mathrm{aq}}^{2+}+2 \mathrm{HCO}_{3(\mathrm{aq})}^{-} .
\end{gathered}
$$

Although there was a little cryoconite at the bare-ice site, there were limited amounts of carbonate, silicate and other soluble materials, which could inhibit chemical reactions such as those described by Eqns (9) and (10). Substantial glacial debris at the supraglacial moraine site, including abundant carbonate, silicate and potash/soda feldspar, generated ample chemical hydrolysis under precipitation or ice/snow meltwater conditions. Such mineral differences between sites can account for the differences in hourly NGE rates.

\section{DISCUSSION}

\section{Errors in the NGE calculation}

In the past, errors in the aerodynamic gradient method used to calculate the atmospheric $\mathrm{H}_{2} \mathrm{O} / \mathrm{CO}_{2}$ flux have been extensively studied for sites in such locations as grassland, forest, tundra and farmland (Wenzel and others, 1997; De Ridder, 2010). In the Koxkar glaciated area, the main factors that influenced NGE accuracy were as follows:

1. The variance, $\pm 5.4 \%$, of $\mathrm{CO}_{2}$ measured by infrared sensors was an objective value, which might cause 4.8 $7.2 \%$ error in the NGE result, with a mean value of $5.3 \%$. The sequential sampling of gas concentrations, sourced from ice melting, at various heights above the ice showed a variability in the gradients due to the non- stationarity of the concentrations. These were obviously not an issue for $u_{*}$, but might be an issue for $\mathrm{CO}_{2}$ flux (Benjamin and others, 2013).

2. A roughness sub-layer correction has been proposed previously (Wenzel and others, 1997; Siqueira and others, 2010; Benjamin and others, 2013). In this work, the roughness sub-layer correction was evaluated based mainly on the approaches of Garratt (1978), Cellier and Brunet (1992) and De Ridder (2010). In general, the error most attributed to the geometric correction for the measurement height of the monitoring equipment was $<15 \%$.

3. The concentration and flux footprint errors are mainly the result of local advection error (Marcolla and others, 2005; Feigenwinter and others, 2010; Novick and others, 2014). Usually, the values of horizontal advection and vertical advection were opposite, and their sums were approximately zero (Feigenwinter and others, 2010; Novick and others, 2014). Calculating the horizontal advection should include at least two flux towers. Hence, the flux footprint error is ignored in this paper.

4. In recent years, englacial gas release has been widely mentioned (Jaworowski and others, 1992; Smellie, 2006; Ryu and Jacobson, 2012). Many studies have suggested that characteristic gases (including $\mathrm{CO}_{2}$ ) from various historical periods may be released from air bubbles within ice (Jaworowski and others, 1992; Anderson and others, 2000; Ryu and Jacobson, 2012). This raises the possibility that future atmospheric $\mathrm{CO}_{2}$ levels will increase as glaciers retreat or disappear. Although this result appears to conflict with the $\mathrm{CO}_{2}$ consumption of negative total NGE as a result of the chemical reactions described here, the total volume will actually decrease by $\sim 10 \%$ during ice melt. If we suppose that the $\mathrm{CO}_{2}$ concentration of glacial air bubbles maintains the higher value of AD 1100 (295 ppmv; Barnola and others, 1995) and that gas pressure inside the bubbles was that of the standard atmosphere, $\mathrm{CO}_{2}$ release was $2.30 \mathrm{mmol} \mathrm{m}^{-2}$ at the bare-ice observation site. This is only $\sim 1.16 \%$ of the NGE rate between Julian days 223 and 268 in 2012. As a result, $\mathrm{CO}_{2}$ release from glacial ice was ignored, whereas the NGE in the glacier region was analyzed. However, released $\mathrm{CO}_{2}$ dissolves in water and participates in chemical reactions between ice-melt water and rocks (Brown, 2002; Jacob and others, 2005).

\section{$\mathrm{CO}_{2}$ storage term}

The $\mathrm{CO}_{2}$ storage term $(S)$ is an important component in the statistical inference of net ecosystem $\mathrm{CO}_{2}$ exchange (NEE) rates (Finnigan, 2006, 2009; Kowalski, 2008; Araújo and others, 2010). There has been little study of $S$ in glacial regions. During the observation period, daily $S$ values ranged from -1.74 to +1.43 and -1.19 to $+1.55 \mathrm{mmol} \mathrm{m}^{-2} \mathrm{~d}^{-1}$ at sites $A$ and $B$, respectively (Fig. 3), with mean values of +0.06 and $-0.03 \mathrm{mmol} \mathrm{m}^{-2} \mathrm{~d}^{-1}$ (about $1.36 \%$ and $0.51 \%$ of total NGE rates). These data demonstrate that $\mathrm{CO}_{2}$ storage $(S)$ rates had little effect on NGE rates in this glaciated area. Given the rapidly increasing glacial surface temperature during daylight hours, $S$ may be positive, resulting in atmospheric $\mathrm{CO}_{2}$ releases below the $\mathrm{CO}_{2}$ detection limit of the infrared sensors. Glacial meltwater was shown to be a fundamental carrier of chemical reactions, producing transient $\mathrm{CO}_{2}$ 


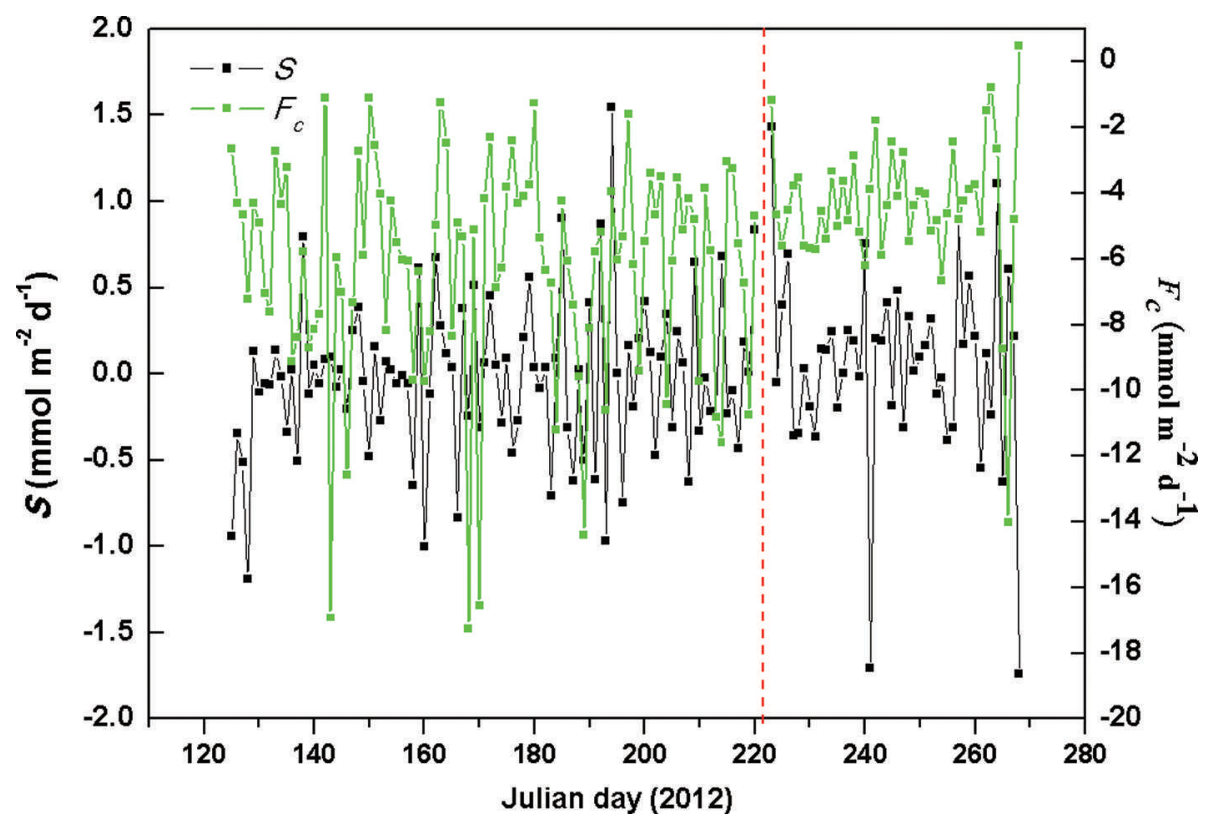

Fig. 3. Study area variations of daily $F_{C}$ and $S$ at sites $A$ and B (right and left sides of vertical dotted line, respectively).

drawdown and decreasing air temperature caused by precipitation. The maximum $S\left(1.55 \mathrm{mmol} \mathrm{m}^{-2} \mathrm{~d}^{-1}\right)$ was caused by sustained heavy rainfall between Julian days 194 and 196 (total precipitation $44.6 \mathrm{~mm}$ ), leading to a decrease in air temperature and a reduction of ice melt, thereby inhibiting chemical reactions.

\section{NGE rates affected by ice-melt intensity (IMI)}

The most obvious characteristic of the NGE rate was that glacial meltwater was the fundamental carrier of carbonate and silicate hydrolysis but was not a determining factor in the daily NGE rates at site B (Fig. 4). Moreover, there were no significant changes in IMI, with daily NGE rates
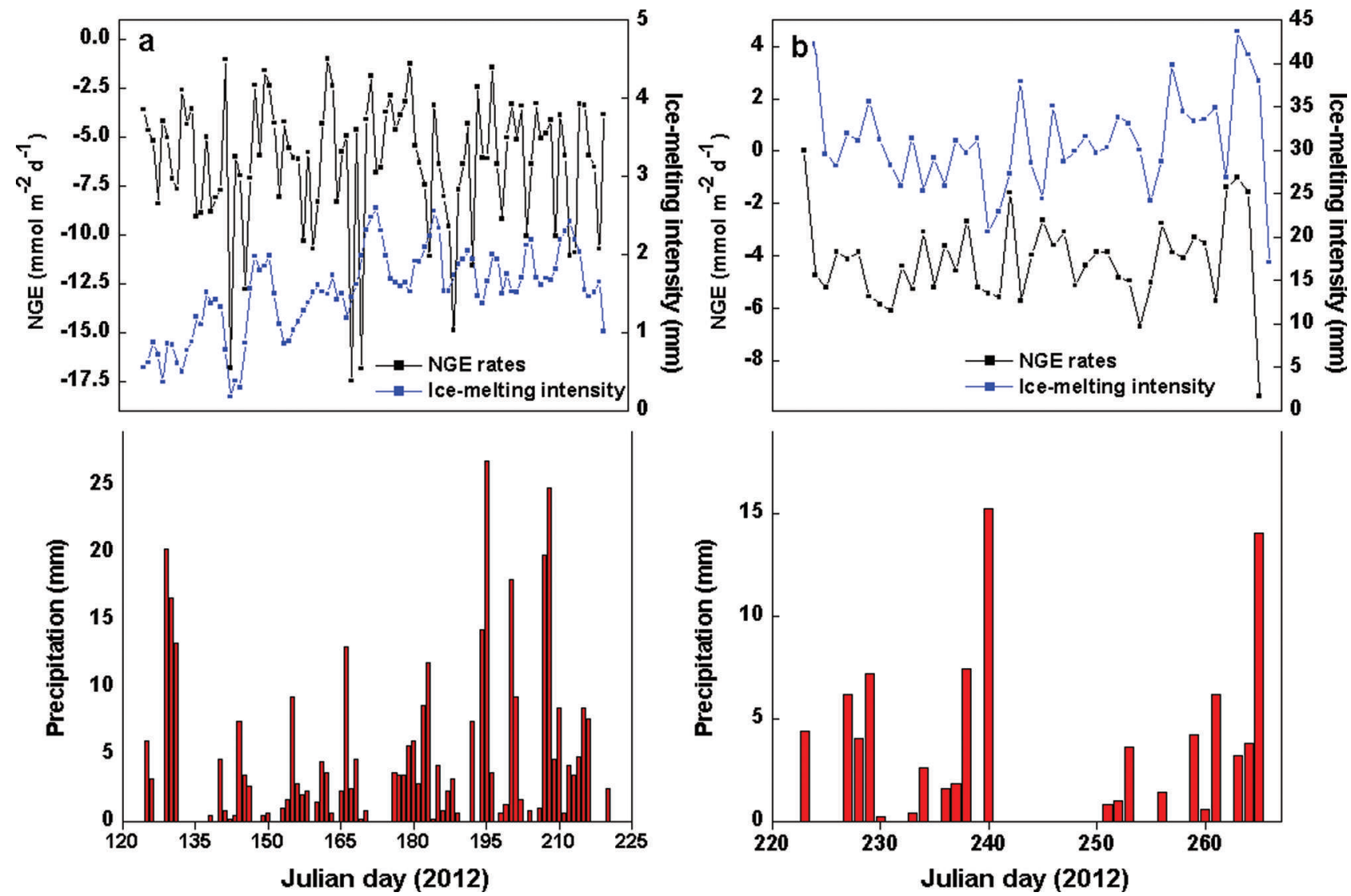

Fig. 4. Relationships of NGE rates, IMI and precipitation at (a) site B and (b) site A. 
Table 2. Relationship between IMI and NGE rates at site B in 2012

\begin{tabular}{lcc}
\hline Julian days & $\begin{array}{c}\text { Ice melting } \\
\mathrm{mm}\end{array}$ & $\begin{array}{c}\text { NGE } \\
\mathrm{mmol} \mathrm{m}^{-2}\end{array}$ \\
\hline 125 (4 May)-153 (1 June) & 9.2 & -179.17 \\
153 (1 June)-183 (1 July) & 70.0 & -180.70 \\
183 (1 July)-215 (2 Aug) & 50.0 & -210.52 \\
215 (2 Aug)-220 (7 Aug) & 9.2 & -30.40 \\
\hline
\end{tabular}

fluctuating around $-6.26 \mathrm{mmol} \mathrm{m}^{-2} \mathrm{~d}^{-1}$ at that site (Table 1). For example, NGE rates at the site were -179.17 and $-30.40 \mathrm{mmol} \mathrm{m}^{-2}$ between Julian days 125 (4 May) and 153 (1 June), and 215 (2 August) and 220 (7 August), respectively. The IMI was consistent across the same periods (Table 2). This suggests that the daily NGE rates are relatively stable with abundant soluble substances, and therefore not remarkably affected by IMI. At site A, however, there was correlation between IMI and NGE rates (Eqn (11)), while daily precipitation was $<2 \mathrm{~mm}$, demonstrating that the daily NGE rates, including those caused by the dissolution of carbonate and silicate, depended on ice melting. A mass of ice-melt water accelerated the strong chemical reactions, leading to a decrease in NGE rate:

$\mathrm{NGE}_{\text {bare-ice }}=-0.063 \cdot \mathrm{IMI}-2.15 \quad\left(R^{2}=0.723 ; n=29\right)$,

where IMI is in $\mathrm{mm}$ and $n$ is the number of days.

Based on these results, it would not be possible to use the ice-melting and NGE rates to calculate the yearly flux of atmospheric $\mathrm{CO}_{2}$ consumption in the Koxkar glaciated region. To estimate the NGE rate for the whole glacial area, we used the degree-day model (Singh and others, 2000; Sicart and others, 2008; Mourshed, 2012; Tennant and others, 2012; Mayr and others, 2013) to calculate the IMI in the bare-ice region, and considered the characteristics of the NGE rate in the supraglacial debris region with the support of GIS, resulting in a daily NGE rate of about $-1.23 \pm 0.17 \mathrm{mmol} \mathrm{m}^{-2} \mathrm{~d}^{-1}$ between Julian days 125 (4 May) and 268 (24 September) in 2012. This estimate is less than the $1.84 \mathrm{mmol} \mathrm{m}^{-2} \mathrm{~d}^{-1}$ that was calculated in terms of ionic mass balance by Wang and others (2010) in 2004, likely by ignoring the chemical reactions that follow glacier surface runoff in englacial conduit geometry. The NGE rate in the Koxkar glaciated area is greater than the $\mathrm{CO}_{2}$ drawdown of the Rhône and Oberaar glacial catchment in the Swiss Alps (Hosein and others, 2004), and also higher than that of the Scottbreen glaciated basin in the Arctic (Krawczyk and others, 2008). Substantial glacial debris might be the main reason for the higher chemical erosion and NGE rates in the Koxkar glacier area (Giles, 2002; Hosein and others, 2004; Krawczyk and others, 2008; Zhang and others, 2013).

\section{CONCLUSIONS}

At Koxkar glacier, atmospheric $\mathrm{CO}_{2}$ concentrations have gradually decreased as atmospheric temperatures have increased. The average values of hourly NGE were approximately -0.05 and $-0.07 \mu \mathrm{mol} \mathrm{m}^{-2} \mathrm{~s}^{-1}$ for bare ice and supraglacial moraine, respectively. This implies that the basin is a sink for atmospheric $\mathrm{CO}_{2}$ above the glacial surface during melting seasons because of existing hydrochemical conditions and mineralogical reactions under ice-melting water. The $\mathrm{CO}_{2}$ storage $(S)$ rates had little effect on NGE rates in the glaciated area, accounting for only $1.36 \%$ and $0.51 \%$ of the total NGE rate at sites $A$ and $B$, respectively. A NGE rate was analyzed in the glacier region. Using the degreeday model to calculate glacial ablation in a bare-ice region, and considering the characteristics of the NGE rate in a region of supraglacial debris with the support of GIS, the daily NGE rate was calculated as approximately $-1.23 \pm 0.17 \mathrm{mmol} \mathrm{m}^{-2} \mathrm{~d}^{-1}$ between Julian days 125 and 268 in 2012 . This could be lower than the actual value, because chemical reactions that follow the process of glacier surface runoff in englacial conduit geometry are not considered.

\section{ACKNOWLEDGEMENTS}

The work was supported by the China National Natural Science Foundation (grant Nos. 41001039, 41130638 and 41130641). We appreciate the comments of two anonymous reviewers.

\section{REFERENCES}

Anderson SP, Drever JI, Frost CD and Holden P (2000) Chemical weathering in the foreland of a retreating glacier. Geochim. Cosmochim. Acta, 64(7), 1173-1189 (doi: 10.1016/S0016-7037 (99)00358-0)

Araújo AC and 11 others (2010) The spatial variability of $\mathrm{CO}_{2}$ storage and the interpretation of eddy covariance fluxes in central Amazonia. Agric. Forest Meteorol., 150(2), 226-237 (doi: 10.1016/j.agrformet.2009.11.005)

Aubinet M, Chermanne B, Vandenhaute M, Longdoz B, Yernaux M and Laitat $\mathrm{E}$ (2001) Long term carbon dioxide exchange above a mixed forest in the Belgian Ardennes. Agric. Forest Meteorol., 108(4), 293-315 (doi: 10.1016/S0168-1923(01)00244-1)

Barnola JM, Anklin M, Porcheron J, Raynaud D, Schwander J and Stauffer B (1995) $\mathrm{CO}_{2}$ evolution during the last millennium as recorded by Antarctic and Greenland ice. Tellus, 47B(1-2), 264-272

Bowling DR and Massman WJ (2011) Persistent wind-induced enhancement of diffusive $\mathrm{CO}_{2}$ transport in a mountain forest snowpack. J. Geophys. Res., 116(G4), G04006 (doi: 10.1029/ 2011JG001722)

Brown GH (2002) Glacier meltwater hydrochemistry. Appl. Geochem., 17(7), 855-883 (doi: 10.1016/S0883-2927(01)00123-8)

Cellier P and Brunet Y (1992) Flux-gradient relationships above tall plant canopies. Agric. Forest Meteorol., 58(1-2), 93-117 (doi: 10.1016/0168-1923(92)90113-I)

Cullen NJ, Mölg T, Kaser G, Steffen K and Hardy DR (2007) Energy balance model validation on the top of Kilimanjaro, Tanzania, using eddy covariance data. Ann. Glaciol., 46, 227-233 (doi: 10.3189/172756407782871224)

De Ridder K (2010) Bulk transfer relations for the roughness sublayer. Bound.-Layer Meteorol., 134(2), 257-267 (doi: 10.1007/s10546-009-9450-y)

Fang R, Shi Y, Lu C and Chen X (2011) Effects of elevated $\mathrm{CO}_{2}$ and $\mathrm{O}_{3}$ and $\mathrm{N}$ fertilization on amount of soil microbial biomass carbon in spring wheat growing season. Procedia Environ. Sci., 8, 34-39 (doi: 10.1016/j.proenv.2011.10.008)

Feigenwinter C, Montagnani L and Aubinet M (2010) Plot-scale vertical and horizontal transport of $\mathrm{CO}_{2}$ modified by a persistent slope wind system in and above an alpine forest. Agric. Forest Meteorol., 150(5), 665-673 (doi: 10.1016/j.agrformet.2009.05.009)

Finnigan J (2006) The storage term in eddy flux calculations. Agric. Forest Meteorol., 136(3-4), 108-113 (doi: 10.1016/j.agrformet.2004.12.010) 
Finnigan J (2009) Response to comment by Dr. A.S. Kowalski on 'The storage term in eddy flux calculations'. Agric. Forest Meteorol., 149(3-4), 725-729 (doi: 10.1016/j.agrformet.2008.10.012)

Garratt JR (1978) Flux profile relations above tall vegetation. Q. J. R. Meteorol. Soc., 104(439), 199-211 (doi: 10.1002/qj. 49710443915)

Guo X and 7 others (2011) Critical evaluation of scalar roughness length parametrizations over a melting valley glacier. Bound.Layer Meteorol., 139(2), 307-332 (doi: 10.1007/s10546-0109586-9)

Han $\mathrm{H}$ and 13 others (2008) Near-surface meteorological characteristics on the Koxkar Baxi Glacier, Tianshan. J. Glaciol. Geocryol., 30(6), 967-975

Han H, Wang J, Wei J and Liu S (2010) Backwasting rate on debriscovered Koxkar glacier, Tuomuer mountain, China. J. Glaciol., 56(196), 287-296 (doi: 10.3189/002214310791968430)

Harman IN and Finnigan JJ (2008) Scalar concentration profiles in the canopy and roughness sublayer. Bound.-Layer Meteorol., 129(3), 323-351 (doi: 10.1007/s10546-008-9328-4)

Hiller R, Zeeman MJ and Eugster W (2008) Eddy-covariance flux measurements in the complex terrain of an Alpine valley in Switzerland. Bound.-Layer Meteorol., 127(3), 449-467 (doi: 10.1007/s10546-008-9267-0)

Hodson A, Porter P, Lowe A and Mumford P (2002) Chemical denudation and silicate weathering in Himalayan glacier basins: Batura Glacier, Pakistan. J. Hydrol., 262(1-4), 193-208 (doi: 10.1016/S0022-1694(02)00036-7)

Hosein R, Arn K, Steinmann P, Adatte T and Föllmi KB (2004) Carbonate and silicate weathering in two presently glaciated, crystalline catchments in the Swiss Alps. Geochim. Cosmochim. Acta, 68(5), 1021-1033 (doi: 10.1016/S0016-7037(03)00445-9)

Jarosch AH, Anslow FS and Shea J (2011) A versatile tower platform for glacier instrumentation: GPS and Eddy Covariance Measurements. In Extended abstracts and recommendations from the IASC Workshop on the Use of Automatic Measuring Systems on Glaciers, 23-26 March 2011, Pontresina, Switzerland. Institute for Marine and Atmospheric Research, University of Utrecht, Utrecht, 52-55

Jaworowski Z, Segalstad TV and Ono N (1992) Do glaciers tell a true atmospheric $\mathrm{CO}_{2}$ story? Sci. Total Environ., 114, 227-284 (doi: 10.1016/0048-9697(92)90428-U)

Jocher G and 7 others (2012) The near-surface small-scale spatial and temporal variability of sensible and latent heat exchange in the Svalbard region: a case study. ISRN Meteorol., 2012, 357925 (doi: 10.5402/2012/357925)

Kang ES, Zhu SS and Huang MM (1985) Hydrological characteristics of the glaciers in Mount Tuomuer, Tien Shan. In Glaciology and meteorology in Mount Tuomuer region, Tien Shan. Academia Sinica. Xijiang People's Press, Ürümqi, 99-119 [in Chinese with English summary]

Kowalski AS (2008) Comment on 'the storage term in eddy flux calculations'. Agric. Forest Meteorol., 148(4), 691-692 (doi: 10.1016/j.agrformet.2007.10.010)

Krawczyk WE and Bartoszewski SA (2008) Crustal solute fluxes and transient carbon dioxide drawdown in the Scottbreen Basin, Svalbard in 2002. J. Hydrol., 362(3-4), 206-219 (doi: 10.1016/ j.jhydrol.2008.08.025)

Krawczyk WE and Pettersson L-E (2007) Chemical denudation rates and carbon dioxide drawdown in an ice-free polar karst catchment: Londonelva, Svalbard. Permafrost Periglac. Process., 18(4), 337-350 (doi: 10.1002/ppp.599)

Lerman A, Wu L and Mackenzie FT (2007) $\mathrm{CO}_{2}$ and $\mathrm{H}_{2} \mathrm{SO}_{4}$ consumption in weathering and material transport to the ocean, and their role in the global carbon balance. Mar. Chem., 106(1-2), 326-350 (doi: 10.1016/j.marchem.2006.04.004)

Liu S, Ding Y, Li J, Shangguan D and Zhang Y (2006) Glaciers in response to recent climate warming in western China. Quat. Sci., 26(5), 762-771 [in Chinese with English summary]

Loubet B and 15 others (2013) Investigating discrepancies in heat, $\mathrm{CO}_{2}$ fluxes and $\mathrm{O}_{3}$ deposition velocity over maize as measured by the eddy-covariance and the aerodynamic gradient methods. Agric. Forest Meteorol., 169, 35-50 (doi: 10.1016/j.agrformet. 2012.09.010)

Lu C, Shi Y and Niu M (2010) Effects of elevated $\mathrm{CO}_{2}$ and $\mathrm{O}_{3}$ on soil amino sugar from wheat straw decomposition in a meadow brown soil of Northeast China. In Soil Solutions for a Changing World, Proceedings of the 19th World Congress of Soil Science, 1-6 August 2010, Brisbane, Australia. International Union of Soil Sciences, 29-32

Macdonald RW, Harner T and Fyfe J (2005) Recent climate change in the Arctic and its impact on contaminant pathways and interpretation of temporal trend data. Sci. Total Environ., 342(1-3), 5-86 (doi: 10.1016/j.scitotenv.2004.12.059)

MacDonell S, Cullen N, Nicholson L, Mölg T and Kinnard C (2010) The behaviour of turbulent heat fluxes on Guanaco glacier, upper Huasco valley, Chile, using eddy covariance data and energy balance modeling. In Abstract Book. International Glaciological Conference (VICC 2010) Ice and Climate Change: A View from the South, 1-3 February 2010, Valdivia, Chile. Centro de Estudios Científicos, Valdivia

Marcolla B, Cescatti A, Montagnani L, Manca G, Kerschbaumer G and Minerbi $S$ (2005) Importance of advection in the atmospheric $\mathrm{CO}_{2}$ exchanges of an alpine forest. Agric. Forest Meteorol., 130(3-4), 193-206 (doi: 10.1016/j.agrformet.2005.03.006)

Mayr E, Hagg W, Mayer C and Braun L (2013) Calibrating a spatially distributed conceptual hydrological model using runoff, annual mass balance and winter mass balance. J. Hydrol., 478, 40-49 (doi: 10.1016/j.jhydrol.2012.11.035)

Mölg T, Hardy DR and Kaser G (2003) Solar-radiation-maintained glacier recession on Kilimanjaro drawn from combined iceradiation geometry modelling. J. Geophys. Res., 108(D23), 4731 (doi: 10.1029/2003JD003456)

Mourshed M (2012) Relationship between annual mean temperature and degree-days. Energy Build., 54, 418-425 (doi: 10.1016/ j.enbuild.2012.07.024)

Novick K, Brantley S, Ford Miniat C, Walker J and Vose JM (2014) Inferring the contribution of advection to total ecosystem scalar fluxes over a tall forest in complex terrain. Agric. Forest Meteorol., 185, 1-13 (doi: 10.1016/j.agrformet.2013.10.010)

Pumpanen J and others (2011) Application of $\mathrm{CO}_{2}$ concentration gradient method for determining soil respiratory fluxes and time delays between photosynthesis and soil respiration. In Kulmala M, Bäck J, Lappalainen HK and Nieminen Teds. Proceedings of the Annual Workshop 'Physics, Chemistry, Biology and Meteorology of Atmospheric Composition and Climate Change', 18-20 May 2011, Helsinki, Finland. (Report Series in Aerosol Science 126) Finnish Center of Excellence and Graduate School, Helsinki http://www.atm.helsinki.fi/faar/reportseries/rs-126.pdf

Raymo ME and Ruddiman WF (1992) Tectonic forcing of late Cenozoic climate. Nature, 359(6391), 117-122 (doi: 10.1038/ 359117a0)

Rinne J, Tuovinen J-P, Laurila T, Hakola H, Aurela M and Hypén $\mathrm{H}$ (2000) Measurements of hydrocarbon fluxes by a gradient method above a northern boreal forest. Agric. Forest Meteorol., 102(1), 25-37 (doi: 10.1016/S0168-1923(00)00088-5)

Roberts DH, Yde JC, Knudsen NT, Long AJ and Lloyd JM (2009) Ice marginal dynamics during surge activity, Kuannersuit Glacier, Disko Island, West Greenland. Quat. Sci. Rev., 28(3-4), 209-222 (doi: 10.1016/j.quascirev.2008.10.022)

Rotach MW, Calanca P, Weigel AH and Andretta M (2003) On the closure of the surface energy balance in highly complex terrain. In Proceedings of the International Conference on Alpine Meteorology (ICAM) and Annual Mesoscale Alpine Programme (MAP) Meeting, 19-23 May 2003, Brig, Switzerland, Volume B. (Publications of MeteoSwiss 66) MeteoSwiss, Locarno Monti, 247-250 http://www.map.meteoswiss.ch/map-doc/icam2003/ ProceedingsB.pdf

Ryu J-S and Jacobson AD (2012) $\mathrm{CO}_{2}$ evasion from the Greenland Ice Sheet: a new carbon-climate feedback. Chemical Geol., 320-321, 80-95 (doi: 10.1016/j.chemgeo.2012.05.024) 
Sharp M, Tranter M, Brown GH and Skidmore M (1995) Rates of chemical denudation and $\mathrm{CO}_{2}$ drawdown in a glacier-covered alpine catchment. Geology, 23(1), 61-64 (doi: 10.1130/00917613(1995)023<0061:ROCDAC >2.3.CO;2)

Sicart JE, Hock R and Six D (2008) Glacier melt, air temperature, and energy balance in different climates: the Bolivian Tropics, the French Alps, and northern Sweden. J. Geophys. Res., 113(D24), D24113 (doi: 10.1029/2008JD010406)

Singh P, Kumar N and Arora M (2000) Degree-day factors for snow and ice for Dokriani Glacier, Garhwal Himalayas. J. Hydrol., 235(1-2), 1-11 (doi: 10.1016/S0022-1694(00)00249-3)

Siqueira MB and Katul GG (2010) An analytical model for the distribution of $\mathrm{CO}_{2}$ sources and sinks, fluxes, and mean concentration within the roughness sub-layer. Bound.-Layer Meteorol., 135(1), 31-50 (doi: 10.1007/s10546-009-9453-8)

Smellie JL (2006) The relative importance of supraglacial versus subglacial meltwater escape in basaltic subglacial tuya eruptions: an important unresolved conundrum. Earth-Sci. Rev., 74(3-4), 241-268 (doi: 10.1016/j.earscirev.2005.09.004)

Solomon S and 7 others eds. (2007) Climate change 2007: the physical science basis. Contribution of Working Group I to the Fourth Assessment Report of the Intergovernmental Panel on Climate Change. Cambridge University Press, Cambridge

Steffen A and 20 others (2008) A synthesis of atmospheric mercury depletion event chemistry in the atmosphere and snow. Atmos. Chem. Phys., 8(6), 1445-1482 (doi: 10.5194/acp-8-1445-2008)

Sutton MA, Pitcairn CER and Fowler D (1993) The exchange of ammonia between the atmosphere and plant communities. Adv. Ecol. Res., 24, 301-393 (doi: 10.1016/S0065-2504(08)60045-8)

Tennant C, Menounos B, Ainslie B, Shea J and Jackson P (2012) Comparison of modeled and geodetically-derived glacier mass balance for Tiedemann and Klinaklini glaciers, southern Coast Mountains, British Columbia, Canada. Global Planet. Change, 82-83, 74-85 (doi: 10.1016/j.gloplacha.2011.11.004)
Tranter M (1996) Glacial runoff as a sink for atmospheric $\mathrm{CO}_{2}$ during the last glacial/interglacial transition. In Bottrell $\mathrm{SH}$ ed. Proceedings of the 4th International Symposium on the Geochemistry of the Earth's Surface, 22-28 July 1996, Ilkley, Yorkshire. University of Leeds, Leeds, 709-713

Tranter $M$ and 8 others (2002) Direct effect of ice sheets on terrestrial bicarbonate, sulphate and base cation fluxes during the last glacial cycle: minimal impact on atmospheric $\mathrm{CO}_{2}$ concentrations. Chem. Geol., 190(1-4), 33-44 (doi: 10.1016/ S0009-2541(02)00109-2)

Valentini R and 29 others (2000) Respiration as the main determinant of carbon balance in European forests. Nature, 404(6780), 861-865 (doi: 10.1038/35009084)

Wang J, Xu JL, Zhang SQ, Liu SY and Han HD (2010) Chemical denudation rates and carbon dioxide sink in Koxkar glacierised region at the south slope of Mt. Tianshan, China. Environ. Sci. (China), 31(4), 903-910 [in Chinese]

Wenzel A, Kalthoff $\mathrm{N}$ and Horlacher $\mathrm{V}$ (1997) On the profiles of wind velocity in the roughness sublayer above a coniferous forest. Bound.-Layer Meteorol., 84(2), 219-230 (doi: 10.1023/ A:1000444911103)

Yde JC, Knudsen NT and Nielsen OB (2005) Glacier hydrochemistry, solute provenance, and chemical denudation at a surgetype glacier in Kuannersuit Kuussuat, Disko Island, West Greenland. J. Hydrol., 300(1-4), 172-187 (doi: 10.1016/ j.jhydrol.2004.06.008)

Zemp M, Frauenfelder R, Haeberli W and Hoelzle M (2005) Worldwide glacier mass balance measurements: general trends and first results of the extraordinary year 2003 in Central Europe. Mater. Glyatsiol. Issled./Data Glaciol. Stud. 99, 3-12

Zhang F, Jin Z, Li F, Yu J and Xiao J (2013) Controls on seasonal variations of silicate weathering and $\mathrm{CO}_{2}$ consumption in two river catchments on the NE Tibetan Plateau. J. Asian Earth Sci., 62, 547-560 (doi: 10.1016/j.jseaes.2012.11.004) 